\title{
DESCRIPTIVE GRADES IN INITIAL MATHEMATICAL TEACHING PARENTS' ATTITUDES
}

\author{
Dževad Burgić ${ }^{1}$ \\ Dalila Avdibegović \\ Edin Tabak
}

University of Zenica

Received: 08.03.2014.

UDC: $371.26: 51$

Original scientific paper

Accepted: 02.04.2014.

\begin{abstract}
$\operatorname{ABSTRACT}^{2}$
Evaluation is very sensitive process in up bring-education work and it is important for comprehensive development of student. More often are fears of different kind, certain forms of unacceptable behavior, are connected with students failure in school and with school evaluation. Grade is feedback on achievements whose purpose is to provide timely information of current level and the steps that are ahead. Numerical grade reflects level of achievements, but there is no indication about elements that makes that grade. Descriptive grade contains key information's about the progress and for that kind of grade you need a lot of words. For student to be descriptively graded, teacher needs to be professionally educated and ready for detailed monitoring and evaluation of student's achievements. Teacher, using appropriate terminology, should successfully describe achievements of student's progress. The school is expected to teach students how to learn and to prepare them for lifelong learning. One of the important factors is also parents. During the time spent with teachers and parents a need has be shown to examine parent's attitudes about descriptive grades in nine-year elementary school. One of the courses that a descriptive grade cannot fully characterize the overall progress of students is mathematics. This course has been chosen because of the problems that parents have when their kids are in first two grades of nine-year elementary school, their attitudes about descriptive grades and difficulties they have when they try to understand student's achievements.
\end{abstract}

Key words: descriptive grades, teaching mathematics, student, parent, attitude.

\section{INTRODUCTION}

With establishing the school as a social institution, occur a need for work evaluation of main participants in school, ie. teachers and students. The issue of evaluation of students achievements has been studied in the past, so we can say that checking of evaluations of students achievements is old almost as is school. Although modern school tends to "catch up" with the development of science and technology and changes in the development of social relations, evaluation is

still at the traditional level. Traditional evaluation is situation where teacher has main part. Difficulties are scales of evaluation that are also as evaluations criteria subjects of social talk.

For proper evaluation are interested not only teachers and students but also the parents and the society at large. Society is directing educations toward demands of the country, so from results of evaluation depends students progress and achieve of certain social status.

\footnotetext{
${ }^{1}$ Correspodence to:

Dževad Burgić, University of Zenica

E-mail: burgic_dz@yahoo.com

${ }^{2}$ This work is a part of research in master work of D. Avdibegović: Teachers and parents' attitudes about descriptive grades in nineyear elementary school, Pedagogical faculty in Sarajevo 2013.
} 
Evaluation means not just measuring the amount of acquired knowledge. The purpose of evaluation may be to determine whether the student has acquired certain knowledge of the matter they are learning, whether does grades are motivating the students, whether does grades encourage him for further work and whether the class had master the subject matter provided by Curriculum. Progress and results are being follow, strive to get more informations about students, tends to be more elements that are affecting final grade and that it is formed based on different ways and shapes of assessments, oral and writting, applying more objective test procedures, tests of knowledge, systematic observation and monitoring of students in all teaching situations.

However, we often encounter the question "Is it possible with descriptive grade to determine the level of knowledge in all subjects?" Descriptive grades in some cases do not provide the whole picture of students' knowledge, so teachers have additional loads that represents problem for them.

Nowdays it is belived that teachers are the one responsible for students failure, while for their success are responsible parents. Parents blame teachers instead of accepting the fact that for students success is needed cooperative work between teacher and parents, and if student is unsuccessful one of these factors is missing.

During the time spent with teachers and parents a need has be shown to examine parents' attitudes about descriptive grades in nine-year elementary school.

\section{EVALUATION, CHECKING AND ASSESS- MENT}

According to Pedagogical dictionary (1950, p. 236), tracking process that involves the whole personality can be described by the term "evaluation, in order to emphasize the difference of assessment as a process of giving a grade."

According Havelka (2000) assessment is part academic theory. With the departure of a child to school, child is expected to be assessed and so to see confirmation of their abilities.

The differences between evaluation and the classical methods of checking of knowledge are in the width of the set goals and methods used. Troj (1957) show difference in the following way:

a) with evaluation we check and measure the broader field of upbring-educational goals of modern school than is achieved by evaluating the individual subjects,

b) to achieve the goal, the evaluation serves many diverse techniques assessments that is related to the success of narrow teaching, that is tested with personality and character tendency tests, which is checked by questionnaires, interviews and special methods of observation and

c) in evaluation process, there is cumulative card of student that helps creating a complete picture of the student.

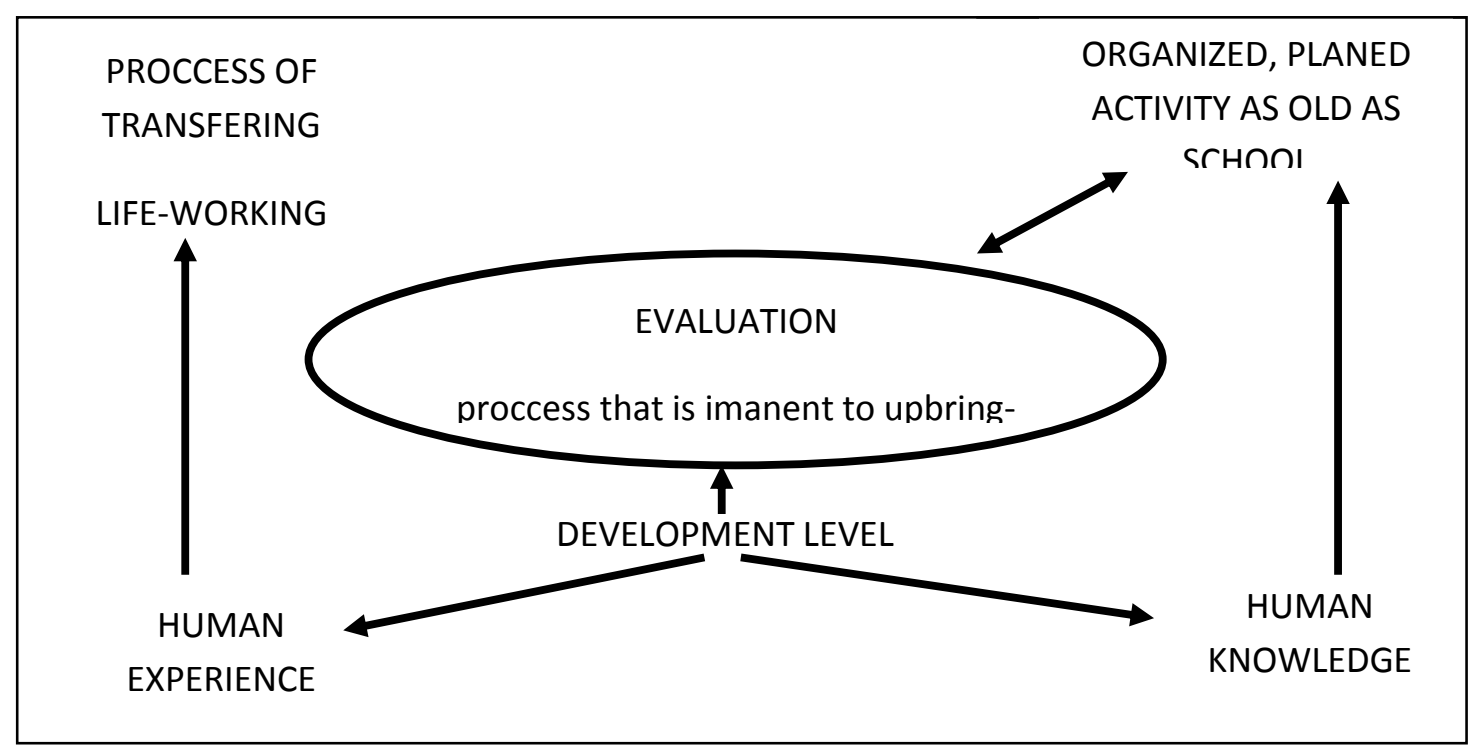

Figure 1. Definition of evaluation with regard to the level of development human knowledge and experience (Kačapor, 2005, p. 25) 
Checking and evaluation are phases of class where teacher gets feedback on the outcome of learning activities. Checking has to be permanent, systematic and comprehensive. Checking and evaluation have to be distinguished as concepts, but in practice they should always be implemented together.

According to Kačapor (etc. 2005), checking means systematic collection of data on how much students approach to desired achievements, i.e. to up bringeducational goals. In general, outcomes of checking are not evaluated.

Checking the knowledge of mathematics is a procedure where teacher during teaching process checks the quality and level up to which the students have acquired certain knowledge, skills and abilities in mathematics.

„The term of assessment is considered to be a process by which, according to established regulations, the upbring-educational students work and students development is followed, and it determines the level student has achieved. "3

When child first starts school, it expects to be assessed in order to see the confirmation of its abilities. In the eyes of student grades are means by which teacher can improve or worsen its position in school or among peers.

The assessment is a part of teaching process and as such as it is, it is implemented throughout the whole of school year. Assessment is a process where teachers assess students' answers because they assume these answers to be reflection of their knowledge.

The most common purpose of assessment is:

a) to provide teachers the feedback on students' progress,

b) to provide feedback to students in order so that they could compare their own progress in overcoming teaching contents with the expected standards,

c) to motivate students,

d) to provide evidence of progress,

e) to point to the readiness of students for future learning.

Modern didactics and theory of special reference to assessment differ several types of assessment, and the most widespread of these are numerical and descriptive assessment. According to T. Prodanović (etc. 1966) there are following types of assessment: numerical assessment, descriptive assessment and combined assessment.

Kyriacou (1991) lists the following types of assessment: formative, summative, normative, diagnostic, internally, externally, informal, formal, permanent and fold.

Numerical assessment represents traditional way of assessment. The lack of numerical assessment is its sidedness, and its advantage is that it at least burden teacher with administration. ${ }^{4}$ Descriptive assessment shows up as an attempt to put the lack of numerical assessment to the minimum. In a process of descriptive assessment student is opserved in general, ie all components of its development.

Descriptive garde is aimed for a student, his parents and teachers. During monitoring of its work and results, a teacher can use professional terminology, but he has to interpretate it to the student and its parents in order so that they could understand clearly the meaning of that grade and the feedback. One of the weakness of this type of assessment is in finding formulation in which the level of knowledge, habits, interests, abilities etc. could be clearly differed.

If we see experience in our neighbor countries on descriptive assessment, i.e. Montenegro, at the very beginning of implementation of this reform, parents were not satisfied with descriptive assessment because they've thought it's not simulative enough and that it's a "trauma for students". But after some time most of them specified that they're satisfied with teachers' work and with descriptive assessment. Descriptive grade gives students enough time to achieve certain goal. A research of the Association of parents in Montenegro on the educational reform showed that parents mostly say that descriptive assessment gives enough information on child's success $(34,9 \%$ completely agree, and 30,7\% agree). But they still claim that descriptive grade doesn't stimulate and motivate the student enough.

\footnotetext{
${ }^{3}$ An encyclopedic dictionary of pedagogy. (1963). Zagreb: Matica Croatia
}

${ }^{4}$ Theme "Education work": Descriptive assessments in I cycle of nine-year elementary school 
Table 1. Sample of monitoring and assessment (the first semester). The first clas (Mulić, 2005)

\begin{tabular}{lcc}
\hline Date & \multicolumn{1}{c}{ Record on work and progress } & Students success \\
& Slowly sees relations: bigger-smaller-equal & Surely solves all tasks \\
Normally draws lines and characters with & prescribed by the programme. \\
triangle. He's careful while drawing. & Gladly draws with triangle, and \\
He's still insecured in subtraction. With the & it's necessary to practice \\
help of specific material he comes up to a & subtraction in a set of numbers \\
solution. & up to 10. With more efforts it \\
Calculates correctly but slowly. & can achieve better results in \\
& mathematics. \\
\hline
\end{tabular}

Pejić (2005) says that descriptive assessment may help to overcome disadvantages of numerical assessment, as such as the following are: assessment of only students' knowledge, and not their abilities, numerical grade says nothing on student itself and its characteristics, we cannot see anything from numerical grade, and how student achieved its success, if he achieved it with its work and contribution or with his abilities, bad grades destimulate, demotivate and discourage student, induce a feeling of inferiority, insecurinty...

Besides listed advantages, descriptive assessment has its certain disadvantages: it's hard for teachers to set formulations for each teaching subject and for each student, it is formed by formulations which don't express important features and characteristics of each student, descriptive assessment cannot present general success of the class or the reasons for failure, descriptive grade is less stimulating than numerical one, and inadequate formulation may destimulate student.

For educators and psychologists there are no doubts on what's better for a child. Descriptive assessment avoids the fear of bad grade or failure, and this fear leads to the loss of confidence and motivation.

Researchers have shown that descriptive assessment has both positive and negative sided. Positive side is that children are not burden with grade. It is very important because in the first class the most important thing is to develop social skills. Negative side is that parents and children don't always understand descriptive grades, so general success is not clear for them when they look at booklets, so some parents prefer numerical assessment.

Combined assessment is used to avoid one-sidedness and disadvantages of specific forms of assessment. 
FACTORS OF ASSESSMENT AND TEACHING MATHEMATICS IN THE 1ST AND 2ND CLASS OF ELEMENTARY SCHOOL

Modern teacher is an organizer and a leader of teaching process, coordinator and mentor, a motivator, an equal collaborator etc. His primary role is to help students in developing their physical and mental potentials and to help them in reaching their individual maximum. Teachers and professors shall constantly professionally improve themselves, all in order to better respond to new requests of society. ${ }^{\text {"65 }}$

The aim of mathematics in the first class of nine-year elementary school is upbringing and education of students based on forming basic mathematical terms, and on acquiring contents as such as comparing subjects according to its characteristics and mutual position (relation), measuring sizes, units of measurement, positive integers up to 10 , relations between them and operations of addition and subtraction are.

Programmed contents represented in teaching mathematics are:

- Comparing, estimating and measuring the size of objects,

- Objects shaped as balls (balls), cylinder, cube, cuboids and pyramid,

- Straight and curved surfaces (surfaces), characters and lines (lines),

- Sets, numbers of relations and operations" (Mulić, 2005, p. 85).

Main outcomes of learning should be:

\section{Knowledge and understanding}

(Students will know how to use mathematical language, how to solve general appropriate mathematical and logical tasks, how to identify data (both known and unknown), to solve arithmetic problems with numerical operations, verbalize process and correctly express the answer. Student shall become aware that he can use mathematics for better understanding of reality and its application in everyday life.)

Abilities

(It shall develop abilities through the game, investing thought efforts in solving specific mathematical situations and their connecting with experiences from its own life.)
Values and attitudes

(A child should be trained for independent work, work in pairs, smaller or larger groups and to show courage in discovering and exploring of new and unknown during that, to respect rules, values personal and others attitudes, to develop communication skills and skills of teamwork.)

Indicators of success:

- They know how to solve problem tasks related to addition and subtraction within the first tens,

- To know how to recognize and name shapes in their environment,

- To gladly solve the tasks.

We come up to the indicators of success by using: practical works, objective tasks and other shapes of evaluation, and portfolio as an indicator of activities in learning process and acquirement of mathematical contents." $" 6$

\section{SUBJECT AND AIM OF RESEARCH}

„Attitude means readiness to react to specific subjects and situations with completely specific feelings, perceptions and ways of behaviour. " (Ćatić, 2003, p.108) An important characteristic of the attitude is that it's hardly changed even when conditions under which it appeared are changed. Attitudes have effect on human behaviour.

Subject of this research are parents' attitudes on descriptive assessment in nine-year elementary school in teaching mathematics.

Since this research will point to a current parents' attitude on descriptive assessment, this research shall have social, theoretical and practical importance.

Based on research results we'll get the image on parents' attitudes towards descriptive assessment in teaching mathematics, and it could be the basis for future researches, ie this research may help in removing difficulties those appear in descriptive assessment and in understanding descriptive grade in the initial teaching of mathematics.

The aim of research is to explore, critically analize and interpretate parents' attitudes towards descriptive assessment in teaching mathematics, five years after introducing descriptive assessment in the first and second class of a nine-year elementary school. 


\section{PROBLEMAND HYPOTHESIS OF RESEARCH}

Based on the results of empirical research, the following problem can be presented within the research to determine what kind of attitude do the parents have towards descriptive assessment in teaching of mathematics.

Hypothesis: Parents have positive attitude on descriptive assessment in nine-year elementary school.

\section{METHODOLOGY AND INSTRUMENTS OF RESEARCH}

In research there'll be used method of analysis of pedagogical theory and method of study of teachers' pedagogical experience.

We used the Scale of attitudes for parents (SSZR) in a research.

Research is implemented with parents whose children go to one of the following schools: Public Institution Elementary School "Isak Samokovlija" Sarajevo, Elementary School "Kulin ban" Visoko and Elementary School "Mula Mustafa Bašeskija" Gornja Zimča.

A sample of parents who were involved in this research is:

Table 2. Sample of parents

\begin{tabular}{cccccc}
\hline & \multicolumn{4}{c}{ Gender } \\
& & Frequency & $\%$ & Valid \% & Cumulative \% \\
\hline \multirow{3}{*}{ Valid } & Male & 30 & 30.0 & 30.0 & 30.0 \\
\cline { 2 - 6 } & Female & 70 & 70.0 & 70.0 & 100.0 \\
\cline { 2 - 6 } & Total & 100 & 100.0 & 100.0 & \\
\hline
\end{tabular}

All of 100 examinee - parents, 30 were males, 70 that mothers were more willing to cooperate than fawere females. Based on this data, we can conclude thers.

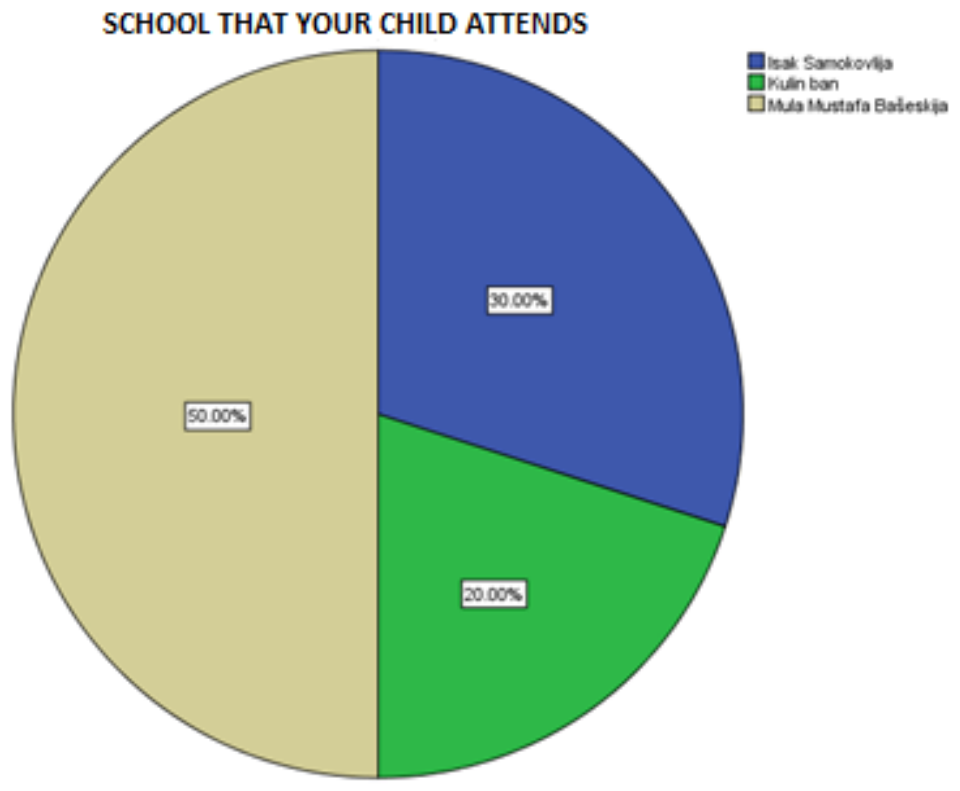

Figure 2. 
$30 \%$ of examinees were parents of children who go from Elementary School "Kulin ban" and 50\% from to Elementary School "Isak Samokovlija", 20\% were Elementary School "Mula Mustafa Bašeskija".

Table 3. The class children attend

\begin{tabular}{cccccc}
\hline \multicolumn{5}{c}{} & \multicolumn{3}{c}{ The class your child attends } \\
& & Frequency & $\%$ & Valid \% & Cumulative \% \\
\hline \multirow{4}{*}{ Valid } & 1 & 20 & 20.0 & 20.0 & 20.0 \\
& 2 & 30 & 30.0 & 30.0 & 50.0 \\
& 3 & 20 & 20.0 & 20.0 & 70.0 \\
& 4 & 30 & 30.0 & 30.0 & 100.0 \\
\cline { 2 - 5 } & Total & 100 & 100.0 & 100.0 & \\
\hline
\end{tabular}

In a research we involved parents whose children at- the second class.

tend the first, the second, the third and the forth class. For our research it was important to explore if these $20 \%$ of total number were parents of the first class, were the parents who have first met with descriptive $30 \%$ were the parents of the forth class, $20 \%$ were the assessment or they have already had experience with parents of the third class and $30 \%$ were the parents of descriptive grades.

Table 4. Number of children who were descriptive assessed during their schooling

\begin{tabular}{cccccc}
\hline \multicolumn{5}{c}{ How many of your children were descriptive assessed during their schooling } \\
& & Frequency & $\%$ & Valid \% & Cumulative \% \\
\hline \multirow{3}{*}{ Valid } & 2 & 44 & 44.0 & 44.0 & 44.0 \\
& $3-4$ & 45 & 45.0 & 45.0 & 89.0 \\
\cline { 2 - 6 } & & 11 & 11.0 & 11.0 & 100.0 \\
\hline
\end{tabular}

Based on general information filled by the parents be- than $50 \%$ of parents have declared that it's not their fore the scale of attitudes, we can notice that more first time to meet with descriptive assessment.

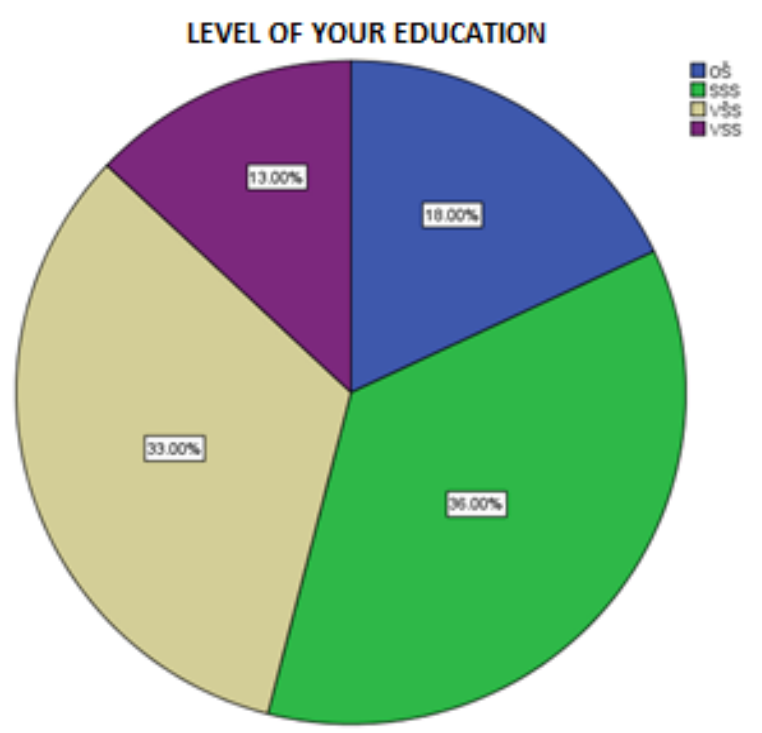

Figure 3. 
It was necessary for our research to notice what professional qualifications of parents are, i.e. the level of their education. During the interpretation of the research outcomes we have tried to relate the parents' attitudes to their level of education.

Within the research related to the parents' attitudes on descriptive assessment in nine-year elementary school parents had a task to show up their attitudes using Likert scale of attitudes for parents. We also wanted to find out if the parents' and teachers' atti- tudes related to descriptive assessment in nine-year elementary school are different.

In data processing we used statistical package SPSS 16.00 for Windows.

We have created two factors (sub-scales) of existing questions and answers:

$\mathrm{g}$ - General attitude on descriptive assessment

$\mathrm{e}$ - Education for descriptive assessment

Bold claims are claims filled by teachers too, which we compared afterwards.

\section{Table 5.}

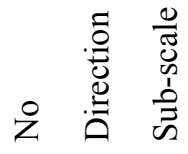

CLAIMS
LEVEL OF MATCHING

\begin{tabular}{|c|c|c|c|c|c|c|c|c|c|c|}
\hline & & & & $\begin{array}{l}\frac{\lambda}{0} \\
\frac{0}{0} \\
\frac{0}{0} \\
0 \\
0\end{array}$ & 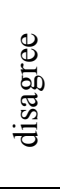 & 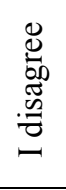 & 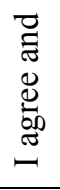 & 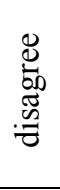 & 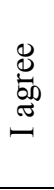 & $\begin{array}{l}\frac{\lambda}{0} \\
\frac{0}{0} \\
\frac{0}{0} \\
0 \\
0\end{array}$ \\
\hline 1 & - & $\mathrm{g}$ & $\begin{array}{l}\text { When a school success in mathematics is shown with } \\
\text { descriptive grade, it's not understandable how much of } \\
\text { knowledge a child has acquired. }\end{array}$ & 0 & & 1 & 2 & & 3 & 4 \\
\hline 2 & - & $\mathrm{g}$ & $\begin{array}{l}\text { Numerical grade clearly shows the level of acquired } \\
\text { knowledge. }\end{array}$ & 0 & & 1 & 2 & & 3 & 4 \\
\hline 3 & - & $\mathrm{g}$ & Formulations of descriptive grades are incomprehensible. & 0 & & 1 & 2 & & 3 & 4 \\
\hline 4 & + & $\mathrm{g}$ & $\begin{array}{l}\text { Descriptive grades are desirable for teaching mathematics } \\
\text { because they specifically show what a child knows, and what } \\
\text { it doesn't know. }\end{array}$ & 0 & & 1 & 2 & & 3 & 4 \\
\hline 5 & + & $\mathrm{g}$ & $\begin{array}{l}\text { Children protect themselves from "demodulation in } \\
\text { teaching", by assessment with descriptive grade. }\end{array}$ & 0 & & 1 & 2 & & 3 & 4 \\
\hline 6 & - & $\mathrm{g}$ & $\begin{array}{l}\text { Children don't find descriptive grade to be as important as } \\
\text { numerical grade is. }\end{array}$ & 0 & & 1 & 2 & & 3 & 4 \\
\hline 7 & - & $\mathrm{g}$ & $\begin{array}{l}\text { Descriptive and numerical grades are usually not 'equal", } \\
\text { i.e. it's not clear how come they suddenly have bad } \\
\text { numerical grades after constant praises during descriptive } \\
\text { assessment. }\end{array}$ & 0 & & 1 & 2 & & 3 & 4 \\
\hline 8 & - & $\mathrm{e}$ & $\begin{array}{l}\text { Teachers should be further trained for application of } \\
\text { descriptive grades. }\end{array}$ & 0 & & 1 & 2 & & 3 & 4 \\
\hline 9 & + & $\mathrm{g}$ & Descriptive grades motivate students to activity. & 0 & & 1 & 2 & & 3 & 4 \\
\hline 0 & - & $\mathrm{g}$ & $\begin{array}{l}\text { There's more partiality at descriptive assessment than at } \\
\text { numerical assessment. }\end{array}$ & 0 & & 1 & 2 & & 3 & 4 \\
\hline $\begin{array}{l}1 \\
1\end{array}$ & - & $\mathrm{g}$ & $\begin{array}{l}\text { Indicators of descriptive assessment don't provide } \\
\text { teacher the possibility to be objective in assessment. }\end{array}$ & 0 & & 1 & 2 & & 3 & 4 \\
\hline
\end{tabular}


Table below shows basic descriptive parameters for both scales. Results show that parents have bad attitude towards descriptive assessment. Values on both scales are below 2 (general attitude is 1.9440 and attitude towards education is 1.2525$)$.

Table 6.

\begin{tabular}{lccccc}
\hline & $\begin{array}{c}\text { Descriptive Statistics } \\
\text { N }\end{array}$ & Minimum & Maximum & $\begin{array}{c}\text { Art. } \\
\text { mean }\end{array}$ & $\begin{array}{c}\text { Stand. } \\
\text { deviation }\end{array}$ \\
\hline $\begin{array}{l}\text { General attitude on descriptive } \\
\begin{array}{l}\text { assessment } \\
\text { Education for descriptive assessment }\end{array}\end{array}$ & 99 & 1.20 & 2.70 & 1.9440 & .33764 \\
\hline
\end{tabular}

Table 7.

\section{Descriptives}

\begin{tabular}{|c|c|c|c|c|}
\hline & & $\mathbf{N}$ & $\begin{array}{l}\text { Art. } \\
\text { mean }\end{array}$ & $\begin{array}{l}\text { Standard } \\
\text { deviation }\end{array}$ \\
\hline \multirow{3}{*}{$\begin{array}{l}\text { Teachers should be further trained for application of } \\
\text { descriptive grades. }\end{array}$} & Teachers & 100 & .70 & .732 \\
\hline & Parents & 99 & 1.25 & .747 \\
\hline & Total & 199 & .97 & .788 \\
\hline \multirow{3}{*}{ Descriptive grades motivate students to activity. } & Teachers & 100 & 2.18 & 1.274 \\
\hline & Parents & 100 & 2.36 & 1.040 \\
\hline & Total & 200 & 2.27 & 1.164 \\
\hline \multirow{3}{*}{$\begin{array}{l}\text { There's more partiality at descriptive assessment than } \\
\text { at numerical assessment. }\end{array}$} & Teachers & 100 & 1.85 & 1.201 \\
\hline & Parents & 100 & 1.63 & .950 \\
\hline & Total & 200 & 1.74 & 1.085 \\
\hline \multirow{3}{*}{$\begin{array}{l}\text { Indicators of descriptive assessment don't provide } \\
\text { teacher possibility to be objective in assessment. }\end{array}$} & Teachers & 100 & 2.03 & 1.275 \\
\hline & Parents & 100 & 2.02 & .816 \\
\hline & Total & 200 & 2.03 & 1.068 \\
\hline
\end{tabular}

If we compare the arithmetic means, data show that teacher worse assess claims:

- Teachers should be further train for application of descriptive grades,

- Descriptive grades motivate students to activity, while parents worse assess following claims:

- There's more partiality at descriptive assessment than at numerical assessment,
- Indicators of descriptive assessment don't provide teacher the possibility to be objective in assessment.

The analysis of variance (ANOVA) shows that both parents and teachers are statistically only different in the first claim "'teachers should be further train for application of descriptive grades", i.e. teachers much more believe that they should be further trained. 
Table 8.

\begin{tabular}{|c|c|c|c|c|c|}
\hline \multicolumn{6}{|c|}{ ANOVA } \\
\hline & & Df & $\begin{array}{c}\text { Art. mean } \\
\text { Square }\end{array}$ & $\mathbf{F}$ & Sig. \\
\hline \multirow{3}{*}{$\begin{array}{l}\text { Teachers should be further } \\
\text { train for application of } \\
\text { descriptive grades. }\end{array}$} & Between Groups & 1 & 15.188 & 27.784 & .000 \\
\hline & Within Groups & 197 & .547 & & \\
\hline & Total & 198 & & & \\
\hline \multirow{3}{*}{$\begin{array}{l}\text { Descriptive grades motivate } \\
\text { students to activity. }\end{array}$} & Between Groups & 1 & 1.620 & 1.198 & .275 \\
\hline & Within Groups & 198 & 1.353 & & \\
\hline & Total & 199 & & & \\
\hline There is more partiality at & Between Groups & 1 & 2.420 & 2.065 & .152 \\
\hline descriptive assessment than & Within Groups & 198 & 1.172 & & \\
\hline at numerical assessment. & Total & 199 & & & \\
\hline Indicators of descriptive & Between Groups & 1 & .005 & .004 & .947 \\
\hline assessment don't provide & Within Groups & 198 & 1.146 & & \\
\hline $\begin{array}{l}\text { teacher the possibility to be } \\
\text { objective in assessment. }\end{array}$ & Total & 199 & & & \\
\hline
\end{tabular}

The following table shows results of descriptive analysis of parents' attitudes compared to their professional qualifications.

Table 9.

\begin{tabular}{|c|c|c|c|c|c|c|}
\hline \multicolumn{7}{|c|}{ Descriptive } \\
\hline & & $\mathbf{N}$ & $\begin{array}{c}\text { Arithmetic } \\
\text { mean }\end{array}$ & $\begin{array}{l}\text { Standard } \\
\text { deviation }\end{array}$ & Minimum & Maximum \\
\hline \multirow{5}{*}{$\begin{array}{l}\text { General attitude on descriptive } \\
\text { assessment }\end{array}$} & OŠ & 18 & 1.8500 & .27062 & 1.30 & 2.30 \\
\hline & SSS & 36 & 1.9583 & .33922 & 1.40 & 2.70 \\
\hline & VŠS & 33 & 1.9121 & .36722 & 1.20 & 2.70 \\
\hline & VSS & 13 & 2.1154 & .30509 & 1.60 & 2.50 \\
\hline & Total & 100 & 1.9440 & .33764 & 1.20 & 2.70 \\
\hline \multirow{5}{*}{ Education for descriptive assessment } & OŠ & 18 & 1.2222 & .94281 & .00 & 3.00 \\
\hline & SSS & 35 & 1.1714 & .74698 & .00 & 2.00 \\
\hline & VŠS & 33 & 1.3333 & .73598 & .00 & 3.00 \\
\hline & VSS & 13 & 1.3077 & .48038 & 1.00 & 2.00 \\
\hline & Total & 99 & 1.2525 & .74701 & .00 & 3.00 \\
\hline
\end{tabular}


With additional test of Analysis of variance (ANOVA) we have determined that there's no statistically significant difference between the attitudes of parents depending on their professional qualifications.

\section{CONCLUSION}

In order to apply descriptive assessment, teacher has to analyze programmed goals, outcomes and contents which are the subject of monitoring and assessment. The aim of this analysis is to determine crucial characteristics of subject for assessment. The list of characteristics is basis for monitoring students' progress and evaluation of its achievements. When making descriptive grade, teacher determines which of these characteristics are fully or partially represented, and which are mostly missing in observed and analyzed activities. Instead of preparing for teaching an average student, teacher is trying to prepare himself for all students in one class. The way students' work is evaluated, recorded and presented has a big influence on the future motivation of a student and on his strategies that he'll be using in his future learning. Descriptive assessment doesn't classify students, but their achievements. It doesn't evaluate a student, but provides specific information on the effectiveness of its engagement and on the quality of its engagement outcome. Based on this information the recommendation for future work is given.

Based on statistical analysis of the scale of parents' attitudes, we came to the conclusion that parents have negative attitude towards descriptive assessment in nine-year elementary school.

Data show that teachers worse assess claims:

- Teachers should be further train for the application of descriptive grades,

- Descriptive grades motivate students for activity. While parents worse assess following claims:

- There's more of partiality at descriptive assessment than at numerical assessment.

- Indicators of descriptive assessment don't give teacher possibility to be objective in assessment.

Analysis of variance (ANOVA) shows that parents and teachers are statistically different only in the first statement which says "Teachers should be further train for the application of descriptive grades", i.e. teachers much more believe they should be further train.

Based on the results of research we didn't confirm our hypothesis that 'Parents have positive attitude towards the descriptive assessment in nine-year elementary school".

In open-ended questions teachers responded that the reason for the lack of descriptive assessment is that parents are less interested for students' work and progress, and that descriptive assessment gives wrong image on students' knowledge.

Teachers suggested to organize seminars where additional knowledge on descriptive assessment would be provided both for teachers and parents, and this would contribute to better mutual understanding of descriptive assessment in the initial teaching of mathematics.

\section{REFERENCES}

Kyriacou, Ch. (2001). Basic teaching principles. Zagreb

An encyclopedic dictionary of pedagogy. (1963). Zagreb: Matica Croatia

Avdibegović, D. (2013). Teachers and parents' attitudes about descriptive grades, master work. Sarajevo: Pedagogical Faculty Troj, F. (1957). Attachment to the issue of checking knowledge and students' assessment in our schools, Beograd

Pejić, M. (2005). Monitoring students' progress and descriptive assessment in Mathematics teaching of first grade in nine-year elementary school, material for teachers, Sarajevo

Havelka, N. (2006). Student and teacher in teaching process, Institute for textbooks and teaching tools, Beograd.

Pedagogical dictionary, (1950). Beograd: Institute for books Socialist Republic of Serbia

Proceedings, (1980). Monitoring and assessment of students, Beograd

Ćatić, R. (2003). Psychology 3. Sarajevo: Svjetlost

Kačapor, S., Vilotijević, M. and Kundačina, M. (2005). The skill of assessment, Mostar

Prodanovi, T., Lekić, Đ., Damjanović and Stefanović, V. (1972).

Research in teaching, Novi Sad

Mulić, V. (2005). Teachers manual for descriptive assessment in nine-year elementary school. Sarajevo: Sarajevo Publishing

Web - sites: http://hr.wikipedia.org/wiki/U\%C4\%8Ditelj

Web - sites: http://portal.skola.ba/start/LinkClick.aspx?fileticke $\mathrm{t}=\mathrm{Q} 5 \mathrm{M} 6 \mathrm{BWW}$ 1HHw\%3D\&tabid=114 